\title{
Testing alternative conceptual models of river-aquifer connectivity and their impacts on baseflow and river recharge processes
}

\author{
Tayyab Mehmood ${ }^{1},{\text { Gretchen } \text { Miller }^{1} \text {, and Peter Knappett }}^{1}$ \\ ${ }^{1}$ Texas A\&M University
}

June 4, 2021

\begin{abstract}
This study characterizes the dynamics of exchange fluxes between Brazos River Alluvium Aquifer and the Brazos River, TX, USA. Seven alternative conceptual models for the connection between the river and the aquifer were simulated in HYDRUS 2D using small-scale, high-resolution transects across the river. These models assumed varying aquifer lithology and river incision depths and considered processes such as riverbed clogging and seepage face flows. The simulations were forced by observed river stage values and tested against observed hydraulic heads in two nearby monitoring wells. The nearly 1.5 years of sub-hourly measurements spanned both flood and drought periods. The best-fit conceptual model supported a hypothesized hydraulic disconnection between the subsurface near the river and the wider alluvial aquifer. In contrast to the assumptions of previous studies, these data were more consistent with the presence of an abandoned paleochannel rather than riverbed clogging or other low-permeability zones. The implications for groundwater-surface water exchanges, and their modelling, are profound. Across the range of models, the difference in average baseflow predicted was nearly $13 \mathrm{~m} 3 / \mathrm{d} / \mathrm{m}$, equivalent to seven times the firm water rights allocated for river users.
\end{abstract}

\section{Hosted file}

2021_mehmood_hyp_Manuscript_final.docx available at https://authorea.com/users/417967/ articles/524866-testing-alternative-conceptual-models-of-river-aquifer-connectivityand-their-impacts-on-baseflow-and-river-recharge-processes 

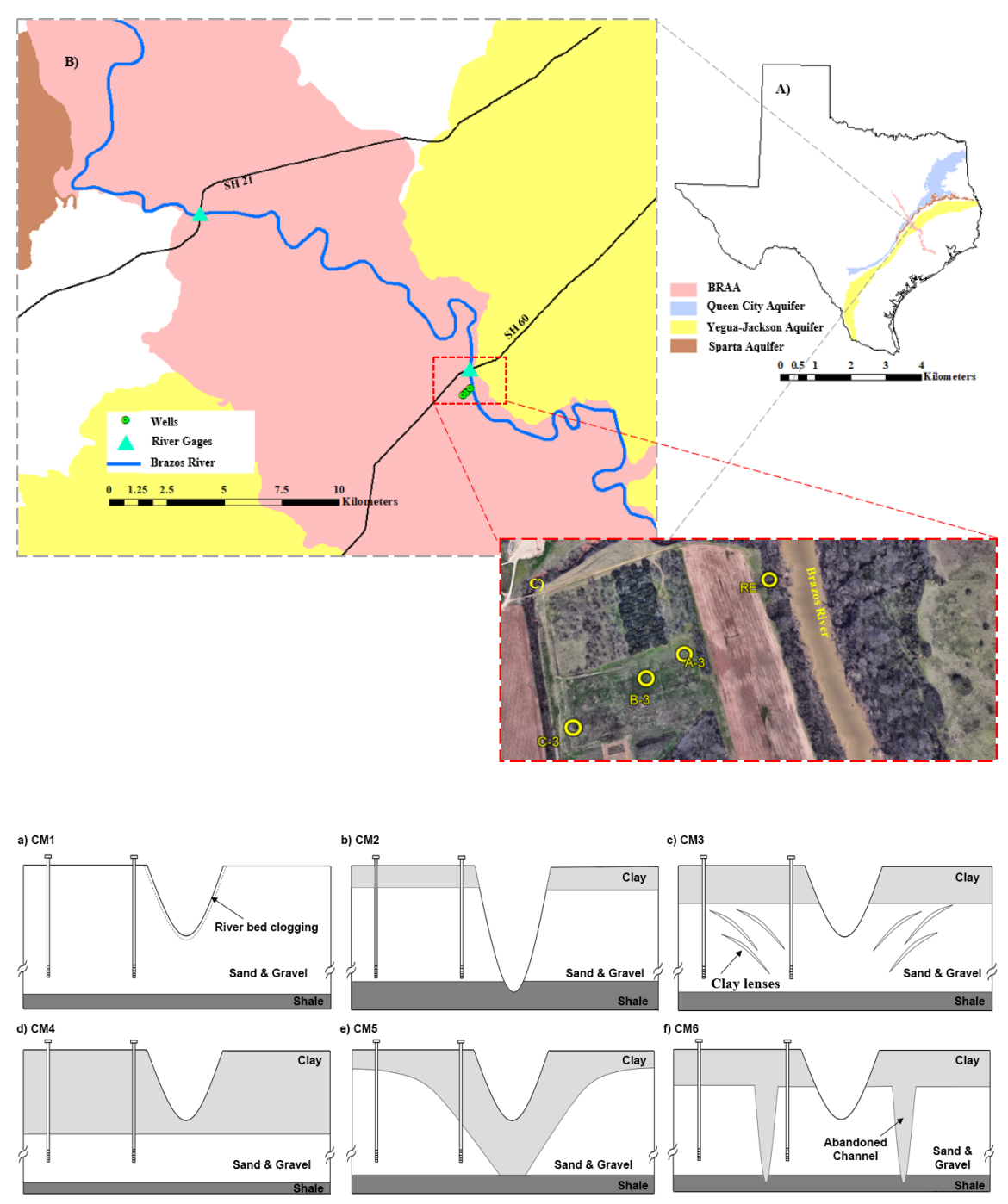

\section{Hosted file}

figure_3.eps available at https://authorea.com/users/417967/articles/524866-testingalternative-conceptual-models-of-river-aquifer-connectivity-and-their-impacts-onbaseflow-and-river-recharge-processes

\section{Hosted file}

figure_4.eps available at https://authorea.com/users/417967/articles/524866-testingalternative-conceptual-models-of-river-aquifer-connectivity-and-their-impacts-onbaseflow-and-river-recharge-processes 
figures/figure-5/figure-5-eps-converted-to.pdf 
figures/figure-6/figure-6-eps-converted-to.pdf 
figures/figure-7/figure-7-eps-converted-to.pdf 
figures/figure-8/figure-8-eps-converted-to.pdf 